\title{
Makna Estetik Pada Bentuk dan Fungsi Pertunjukan Topeng Banjet Abah Pendul Kab.Karawang
}

\author{
${ }^{1}$ Rudi Hartono, ${ }^{2}$ Jaeni, ${ }^{3}$ Wanda Listiani \\ 1.2.3Institut Seni Budaya Indonesia (ISBI) - Bandung \\ Jl. Buah Batu No.212, Cijagra, Kec. Lengkong, Kota Bandung, Jawa Barat \\ Email: rudih5807@gmail.com @jenteaterwot@yahoo.com@wanda_96@yahoo.com
}

\begin{abstract}
Abstrak:Artikel ini mengupas makna estetik Pertunjukan Topeng Banjet Abah Pendul yang lahir dari ide atau gagasan masyarakatnya, dalam hal ini pertunjukan teater rakyat hidup dan berkembang ditengah-tengah masyarakanya tentunya memiliki bentuk dan fungsi. Pendekatan yang digunakan adalah pendekatan strukturalisme semiotik model Levi-Strauss yang menjelaskan suatu objek kajian secara struktural melalui dari dua sisi yaitu struktur luar yang dikenal dengan istilah surface structure dan struktur dalam yang dikenal dengan istilah deep structure. Pertunjukan dalam masyarakat dimana Topeng Banjet tersebut berada dan terjadi peristiwa komunikasi budaya dalam intraksi sosial antara pertunjukan dan penonton. Tujuan artikel ini adalah untuk menggali apa makna estetik yang ada pada pertunjukan Topeng Banjet Abah Pendul. Pentingnya penelitian ini untuk mengetahui korelasi-korelasi makna estetik seni pertunjukan. Metode penelitian yang digunakan yaitu kualitatif dengan mengacu pola struktur bentuk dan fungsi pertunjukan yang bersifat deskritif naratif dengan triangulasi dan dokumentasi pertunjukan. Dalam hasil uraian struktur pertunjukan, mengurai, menganalisis dan menjelaskan makna estetik dalam seni pertunjukan Topeng Banjet Abah Pendul dalam masyarakat Karawang.
\end{abstract}

Kata kunci : Komunikasi, Budaya Makna Estetik, Topeng Banjet Abah Pendul

Abstract: This article examines the aesthetic meaning of Abah Pendul's Banjet Mask Show which was born from the ideas or ideas of the community, in this case folk theater performances live and develop in the midst of their society, of course, have form and function. The approach used is the semiotic structuralism approach of the Levi-Strauss model which describes an object of study structurally through two sides, namely the outer structure known as the surface structure and the inner structure known as the deep structure. Performances in the community where the Banjet Mask is located and cultural communication events occur in the social interaction between the show and the audience. The purpose of this article is to explore the aesthetic meaning of the Abah Pendul Banjet Mask show. The importance of this research is to determine the correlations of the aesthetic meaning of performing arts. The research method used is qualitative by referring to the structure pattern of the form and function of the performance which is descriptive narrative with triangulation and documentation of performances. In the results of the description of the performance structure, parsing, analyzing and explaining the aesthetic meaning in the performing arts of the Banjet Abah Pendul Mask in the Karawang community.

Keywords: Communication, Aesthetic Meaning Culture, Abah Pendul Banjet Mask

\section{PENDAHULUAN}

Topeng Banjet Abah Pendul salah satu kesenian rakyat sebagai fenomena budaya, pada dasarnya fenomena kesenian adalah suatu bentuk ekspresi, sebagai perwujudan atau simbolisasi dari perasaan dan pikiran manusia, tercakup pula pandangan-pandangannya atau nilai-nilai yang dianutnya. Perasaan atau pandangannya tersebut ingin diceritakan, dikomunikasikan kepada orang lain. Bila demikian, seperti halnya bahasa, maka 
fenomena kesenian merupakan wahana komunikasi pertunjukan. Artinya kesenian disini sebagai bahasa yang memiliki system structural.

Pada awalnya Topeng Banjet adalah sebagai pelengkap upacara tradisional seperti dalam kegiatan setelah panen padi yang dilakukan pada masa-masa lalu sebagai ungkapan syukur kepada Tuhan Yang Maha Esa yang telah memberikan hasil panen yang telah diperoleh. Topeng Banjet yang hidup di Karawang bentuk penyajiannya hampir mendekati tahun 1920-an masih dipertahankan oleh grup Bang Pendul dari Kecamatan Rawamerta, sejak 1993 menjadi Kecamatan Tempuran dan sekarang menjadi Cilamaya Kulon Hamid dalam Supriatna,(2010:63) dikutip dari Rosala.D,dkk (2018). Dalam perkembangannya kesenian Topeng Banjet Abah Pendul digunakan pula dalam kegiatan lainnya seperti dalam acara hiburan hajatan perkawinan, khitanan, acara penyambutan tamu, pesta-pesta, juga pada acara hiburan peringatan hari-hari nasional, serta acara hiburan lainnya. Pertunjukan Topeng Banjet Abah Pendul dimaksudkan untuk menyampaikan pesan-pesan heroik melalui, cerita jawara, roman sejarah, kisah rumah tangga dan berisi adegan lawakan. Dalam pertunjukan Topeng Banjet Abah Pendul tidak bisa dipastikan jumlah pemain yang terlibat namun dapat di bagi, pemain, pemusik dan penari. Dalam hal ini pemain adalah mereka yang melaksanakan kegiatan yang meliputi pemain dan nayaga. Dan para pemain yang dibutuhkan adalah satu orang penari topeng inti, satu orang atau dua orang penari topeng pembantu yang merangkap menjadi pelawak wanita, 3 orang laki-laki yang merangkap sebagai pemain, lima orang penabuh waditra yang merangkap juga menjadi pemain pembantu. Pertunjukan teater rakyat seperti halnya Topeng Banjet, yaitu improvisasi, sederhana, spontan dan menyatu dengan kehidupan rakyat.

Pertunjukan budaya local dalam hal ini Topeng Banjet Abah Pendul di daerah Kab.Karawang yang digunakan oleh warga masyarakat pendukungnya untuk 
berkomunikasi. Dell Hymes (1973) memandang komunikasi sangat penting sebagai salah satu unsur dalam memahami budaya, seperti halnya seni pertunjukan yang ada di masyarakat dengan menyebutkan empat komponen komunikasi dari budaya tersebut, yakni meliputi :pesan komunikasi, peserta, komunikasi, sandi yang digunakan, serta media atau saluran, (Rahmat, 2000;244) dikutip dari Jeani (2017). Dalam proses pertunjukan Topeng Banjet berlangsung proses komunikasi antara pemain dan penonton yaitu adanya pesan yang ditangkap melalui pengindraan dan dimaknai secara estetik melalui bahasa,tanda, petanda dimana simbol yang berfungsi sebagai elemen pendukung artistik memberikan dukungan secara estetik dalam pertunjukan.

Pertunjukan Topeng Banjet Abah Pendul untuk menggali makna sesuatu objek, gejala, atau peristiwa melalui struktur bentuk dan fungsi. Sebab esensi makna ada pada peristiwa struktur pertunjukan. Melihat peristiwa pertunjukan sebagai objek secara langsung di telaah dan dianalisis melalui peristiwa tersebut. Kehadiran segala unsur elemen artistiknya, pola penyajian, tari, music, pemain, lakon cerita, penonton dan terjadi peristiwa pertunjukan sehingga dapat di gali maknanya. Makna (meaning) secara umum, didapatkan dari menggali tanda-tanda, Berger (2010: 245). Tanda adalah sesuatu yang bagi seseorang berarti sesuatu yang lain. Kajian semiotika memfokuskan tiga wilayah, yaitu (1) Tanda itu sendiri. Wilayah ini meliputi kajian mengenai berbagai jenis tanda yang berbeda, cara-cara berbeda dari tanda-tanda didalam menghasilkan makna, dan cara tanda-tanda tersebut berhubungan dengan orang yang menggunakannya. Tanda adalah konstruksi manusia dan hanya bisa dipahami didalam kerangka penggunaan/konteks orang-orang yang menempatkan tanda-tanda tersebut: (2) Kode-kode atau sistem dimana tanda-tanda diorganisasi. Kajian ini melingkupi bagaimana beragam kode telah dikembangkan untuk memenuhi kebutuhan masyarakat atau budaya, atau untuk mengeksploitasi saluran-saluran komunikasi yang tersedia bagi pengiriman kode-kode 
tersebut; dan (3) Budaya tempat dimana kode-kode dan tanda-tanda beroperasi. Hal ini pada gilirannya bergantung pada penggunaan dari kode-kode atau tanda-tanda untuk eksistensi dan bentuknya sendiri (Fiske, 2012).

Melalui prinsip dasar dan pendekatan Strukturalisme Levi - Strauss adalah bahwa struktur social tidak berkaiatan dengan realitas empiris, melainkan dengan model-model yang dibangun menurut realitas empiris tersebut Strauss, (2007:378) dalam Restu, dkk dikutip dari Restu Budi Setiawan (2015). Dalam menganalisa dan mempelajari tentang hubungan struktur bentuk dan fungsi, mengurai kolerasi dan logika-logika dalam perisitiwa komunikasi budaya dalam menggungkapkan maknanya. Teori Strukturalisme Levi - Strauss merupakan teori yang berfungsi untuk analisis struktural dan membedakan struktur menjadi dua macam; struktur luar (surface structure) dan struktur dalam (deep structure). Struktur luar adalah relasi-relasi antar unsur yang dapat kita buat atau bangun berdasarkan atas ciri-ciri luar atau ciri-ciri empiris dari relasi-relasi tersebut, sedangkan struktur dalam adalah susunan tertentu yang kita bangun berdasarkan atas struktur lahir yang telah berhasil di buat, namun tidak selalu tampak pada sisi empiris dari fonomena yang kita pelajari. Struktur dalam inilah yang lebih tepat dipakai sebagai model memahami fenomena yang diteliti, karena melalui struktur inilah peneliti kemudian dapat memahami berbagai fenomena budaya yang dipelajarinya, dalam Ahimsa-Putra, (2009:66)

Sementara untuk pemaknaan menurut Yanti Heriyanti (2016;39), Ujaran manusia itu mengandung penuh makna yang utuh. Keutuhan makna itu merupakan perpaduan dari aspek, yakni pengertian (sense), perasaan (feeling), nada (tone), dan amanat (intension). Memahami aspek itu dalam seluruh konteks adalah bagian dari usaha untuk memahami makna dalam komunikasi. Dapat di artikan dalam menggali makna dengan menafsir 
berlandaskan keempat hal unsur tersebut diatas saling berhubungan erat dan masingmasing memberi sumbangan bagi proses pembentukan makna.

Untuk karya seni disusun sedemikian rupa bahasa dan gerak sehingga menjadi karya yang estetik. Sementara untuk estetika sebagai filsafat tentang pencerapan indrawi. Pengertian ini berakar pada penemuan disiplin estetika oleh Aleksander Baumgarten pada Abab Ke-18 yang menurut asal istilahnya dari kata Yunani, aesthesis ("pencerapan indrawi"). Pengertian semacam ini berhubungan dengan pengertian pertama sebab “pencerapan indrawi” yang dimaksud Baumgarten adalah pencerapan indrawi atas hal-hal yang indah (cognition aesthetica) di kutip dari Martin Suryajaya (2016;841). Kesenian yang merupakan hasil kebudayaan dari manusia yang disebut juga unsur unsur kebudayaan_ yang memilki nilai keindahan akan tetapi memiliki kesan dihati orang lain sebagai penikmat seni melalui yaitu; melihat, mendengar, merasakan, menikmati dengan segenap pencerapan indra setiap individu. Komunikasi estetik merupakan kalimat lain dari komunikasi keindahan, yang menjadi inti dari komunikasi seni. Keindahan bukanlah objek fisik melainkan suatu fenomena yang dirasakan melalui pengamatan inderawi berdasarkan pengalaman estetis, Jaeni (2017: 48).

Menyaksikan Pertunjukan Topeng Banjet Abah Pendul di dalamnya ada lagu, tari, musik dan cerita lakon, dan kelompok masyarakat yang menyaksikan tontonan tersebut akan terjadi interpretasi dan analisis struktur terhadap bentuk dan fungsi pertunjukan tersebut sebagai wujud karya seni dimana terkandung nilai-nilai makna estetik. Dalam pertunjukan Topeng Banjet pesan makna menjadi inti dari pertunjukan. Pengelolahan pesan diwujudkan melalui simbol-simbol diatas panggung. Di sinilah letak seni pementasan tersebut. Bagaimana sebuah tontonan menjadi media komunikasi dengan menggunakan bahasa artistik, Eko Santosa (2020:33). 
Penelitian ini pada kelompok Topeng Banjet Sinar Pusaka Warna Abah Pendul atau biasa disebut Topeng Banjet Abah Pendul yang beralamat di Dusun Jl. Bayur No.02 Rt 009/003, Lemah duhur, Tempuran, Kabupaten Karawang, Jawa Barat. Topeng Banjet Abah Pendul berdiri sejak 1912. Hasil wawancara Tanggal 7 September 2020. Wa. Doris

\section{METODELOGI PENELITIAN}

Metode penelitian yang digunakan peneliti dalam hal ini adalah pendekatan kualitatif dengan metode deskriptif. Metode penelitian yang digunakan adalah metode kualitatif. "Metodologi adalah proses, prinsip, dan prosedur yang kita gunakan untuk mendekati problem dan mencari jawaban” (Mulyana, 2008: 145). Menurut Sugiyono (2007:1) dikutip dari Ditha Prasanti (2018), metode penelitian kualitatif merupakan suatu penelitian yang digunakan untuk meneliti pada objek yang alamiah dimana peneliti adalah sebagai instrumen kunci, teknik pengumpulan data dilakukan secara gabungan, analisis data bersifat induktif, dan hasil penelitian kualitatif lebih menekankan makna daripada generalisasi. Penelitian kualitatif bertujuan mempertahankan bentuk dan isi perilaku manusia dan menganalisis kualitas-kualitasnya, alih-alih mengubahnya menjadi entitasentitas kuantitatif (Mulyana, 2008: 150) dikutip dari Ditha Prasanti (2018). Tujuan dari penelitian deskriptif ini adalah untuk membuat deskipsi, gambaran atau lukisan secara sistematis, faktual dan akurat mengenai fakta-fakta, kolerasi serta hubungan antar fenomena yang diselidiki.

Data Teknik pengumpulan data dalam penelitian kualitatif adalah dengan melakukan observasi, wawancara, dan dokumentasi. 1) Observasi yang dilakukan dalam penelitian ini adalah pengamatan. Pengamatan dilakukan dengan cara non participant observation terhadap peristiwa pertunjukan Topeng Banjet Abah Pendul . 2) Wawancara dilakukan untuk mengetahui untuk melengkapi data dan upaya memperoleh data yang akurat dan sumber data yang tepat. Dalam penelitian ini, penulis mewawancarai 3 orang informan, 
yang terdiri dari 2 orang palaku seni dan 1 penaggap. 3) Studi Dokumentasi dalam penelitian ini diperlukan untuk mempertajam analisis penelitian yang berkaitan dengan tamu undangan dan penonton dalam pertunjukan. Data didapat dari hasil observasi, wawancara dan dokumentasi selanjutnya di analisis secara struktur bentuk dan fungsi dapat menentukan pada tingkat mana kolerasi-kolerasi tersebut terjalin hingga peneliti mendapat asumsi dasar yang kuat dan melakukan kesimpulan lewat pengkajian silang dengan pakar atau seniman. Di samping itu juga menggunakan member cheking yakni meminta pengecekan dari sumber irforman, pemain, dan penonton.

Validasi data dilakukan dengan menggunakan teknik triangulasi sumber, dan dianalisis menggunakan teknik analisis struktur bentuk dan fungsi dengan menggunakan metode induktif dengan model interaktif. Dalam hal ini Miles and Huberman (1984) dikutip dari Noning Verawati (2016) menyatakan bahwa yang paling sering digunakan untuk menyampaikan data dalam penelitian kualitatif adalah dengan teks yang bersifat naratif.

Untuk menguatkan hasil penelitian tiga komponen meliputi reduksi data, sajian data, dan penarikan simpulan/verifikasi pemahaman tersebut maka peneliti akan menguraikan data-data yang sudah direduksi dan menyimpulkan hasil data tersebut melalui sebuah teks.

\section{HASIL DAN PEMBAHASAN}

\section{Hasil Penelitian Pada Bentuk Pertunjukan Topeng Banjet Abah Pendul}

Berdasarkan observasi yang telah dilakukan terhadap pertunjukan Topeng Banjet Abah Pendul ditemukan beberapa struktur penyajian dalam pertunjukan. Adapun identifikasi dari struktur bentuk dalam pertunjukan Topeng Banjet Abah Pendul tersebut adalah sebagai berikut :

1. Ritual Pertunjukan Sesaji dan Ngukus 
Perlengkapan sesaji yang sudah di siapkan oleh penanggap dalam pelaksanaan ritual di awal penyajian yang merupakan tata cara yang tidak dapat pisahkan dari penyajian pertunjukan Topeng Banjet Abah Pendul. Ritual awal ini sebelum pertunjukan dikhususkan dan bagian penting yang merupakan satu kesatuan dari seluruh rangkaian penyajian kesenian Topeng Banjet Banjet Abah Pendul. Kegiatan ini sebagai upacara ucapan syukur permohonan dan memanjatkan do'a atas keberkahan dan keselamatan dari para leluhur (karuhun) dan terkhusus kepada Tuhan Yang Maha Esa. Setelah itu pertunjukan Topeng Banjet Abah Pendul segera akan dimulai.

Ritual ini, dilakukan oleh seorang pimpinan Topeng Banjet Abah Pendul atau yang dituakan Abah Syahrul Putra Pendul sebelumnya persyaratan sesaji telah tersedia. Ada maksud dari kegiatan ritual ini, sebagaimana disampaikan Abah Syahrul Putra Pendul adalah untuk memohon dan memanjatkan puji syukur atas berkah dan keselamatan yang telah diberikan para leluhur (karuhun) dan kepada Tuhan Yang Maha Esa sekaligus agar mendapatkan restu kelancaran, kesuksesan dalam pertunjukan begitu juga kepada yang punya hajat serta penonton yang datang. (Wawancara, 26 September 2020 di Jatiragas Kab Karawang)

Jenis-jenis sesaji yang biasa disediakan dalam pertunjukan Topeng Banjet Abah Pendul ini adalah: Gabah, Ayam bakar bakakak dalam karung ditutup kain putih, Tempat pembakaran kemenyan, rujak-rujakan, air, pisang, kue-kue, kolak pisang, beras, kelapa muda, telur ayam, rokok, daun pandan, air dan kembang bunga.

Gambar. 1. Perlengkapan Sejaji diatas Peti Gambar.2. Sesaji diatas Peti
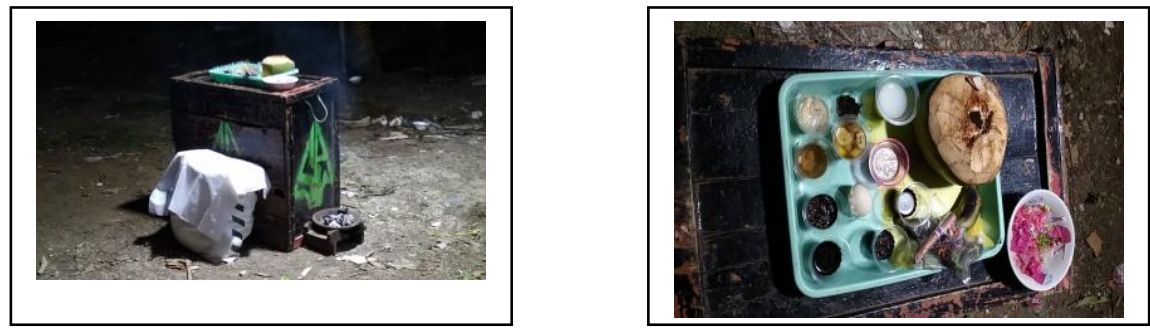

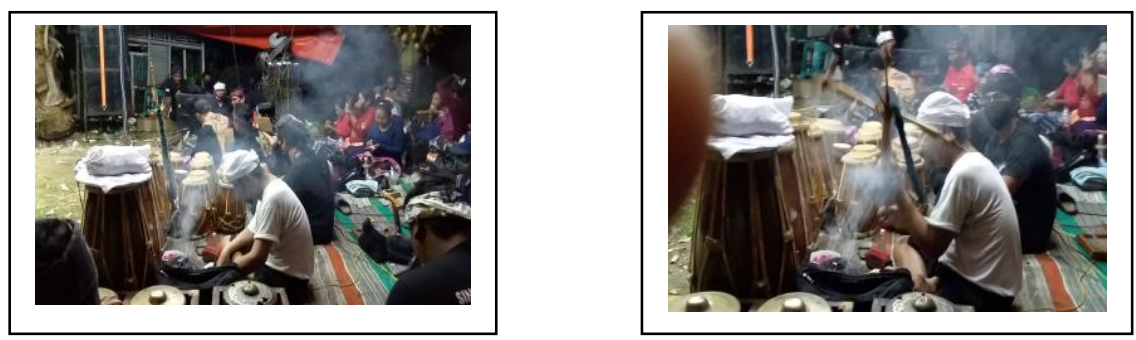

(Sumber Gambar;1,2,3,4: Rudi Hartono 2020)

Menurut Jakob Sumardjo, 2007:25 (dalam Jaeni 2017;68) bahwa seni pertunjukan Indonesia, masih memiliki sifat transenden. Sifat ini dapat dilacak dari seni-seni pramodern yang menyimpang pola pikir paradoks, yaitu pola pikir yang diartikan sebagai wujud berpasangan dan saling melengkapi (completion oppositorum). Peristiwa pertunjukan itu tersimpan peristiwa komunikasi transcendental yang menghadirkan keramat (karomah) dan mendapatkan berkah (barokah).

Acara ngukus sebelum pertunjukan mutlak diikuti seluruh anggota kelompok topeng banjet yang akan main. Terasa kental ritual setelah pimpinan topeng membaca matra dan setelah itu lalu mengambil alat musik rebab di depannya lalu tepat diatas tempat pembakaran kemenyan asap yang keluar diusapkan keseluruh bagian alat musik rebab. Tempat pembakaran kemenyan yang sementara mengeluarkan asap, lalu di pindah secara bergiliran kepada pemusik, pemain, penari, asap yang ke luar di usapkan ke bagian muda dan bagian tubuh. Uniknya bukan saja para pendukung namun alat musik di perlakukan sama demikian artinya asap yang keluar di tempat pembakaran kemenyan diusapkan juga ke alat yang di pake, tambah kembang bunga dan air yang juga sudah di bacakan do'a saat ngukus digilir demikian juga penggunaannya. Ada perlakuan khusus goong yang dibungkus kain putih dan baju penari topeng (ronggeng) Ketul Tilu juga di bungkus kain putih sebelum dan sesudah pertunjukan disimpan di tempat khusus. 
Gambar. 5.

Air Kembang di Percikan

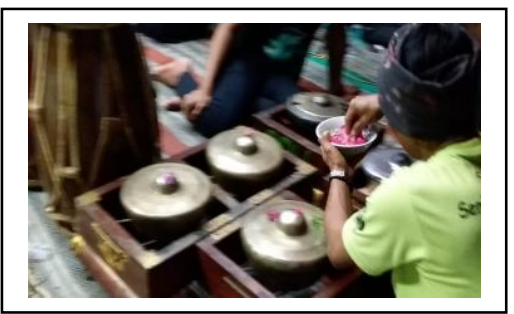

Gambar. 6.

Asap yang keluar dari tempat pembakaran kemenyan di usapkan ke bagian muka dan badan pemain)

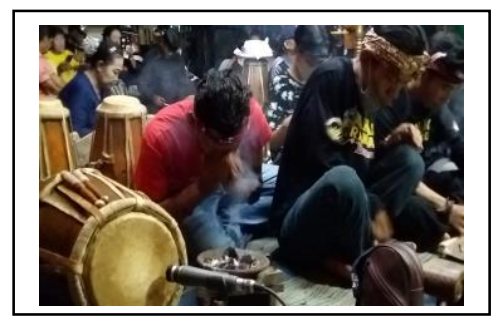

(Sumber Gambar: 5,6; Rudi Hartono 2020)

2. Musik Pembuka (Tatalu)

Tetalu iringan musik pembukaan pada Topeng Banjet Abah Pendul ditandai pertama dengan gesekan rebab yang begitu terasa seolah-olah hening kedalaman mengantar kita. Musik pembukaan terbagi dari iringan musik tataluan panjang dan iringan musik tatalu pendek masuk lagu arang-arang. Penyajian musik pembukaan memiliki fungsi yang berbeda. Iringan tatalu panjang dengan tabuhan khas Topeng Banjet sesuai dengan aslinya disajikan selama \pm 45 menit menandai bahwa pertunjukan Topeng Banjet sudah dimulai dan penonton dipersilahkan mengambil tempat duduk atau posisi di sekitar tempat pertunjukan. Iringan musik penyajian tatalu pendek disajikan selama \pm 15 menit, musik tabuhan khas Topeng Banjet Abah Pendul dengan masuknya unsur-unsur senggak (iringan vocal pendek) dan tepuk dan sorak berfungsi membangun keterlibatan seluruh pemain utama dan pendukung dan sekaligus menjadi penanda bahwa para pemain sudah siap pentas.

Penyajian iringan musik tatalu panjang dan pendek usai digelar masuk pada lagu arang-arang disajikan beberapa saat. Kekhasan lagu ini, terletak pada keset rebab disajikan tanpa musik lain. Usai lagu arang-arang dilanjutkan lagu perkenalan kelompok Topeng Banjet Abah Pendul, kemudian lagu menyerupai kidung sebagai lagu pembukaan mengucap permohonan agar diberikan berkah dan keselematan dari 
Tuhan Maha Maha Esa bagi yang punya hajat di berikan keberkahan, keselamatan tamu undangan dan warga kampung (penonton).

Waditra atau peralatan musik tabuhan sebagai pengiring pertunjukan Topeng Banjet Abah Pendul terdiri dari: rebab, kendang, goong anggong, rebab, kecrek, ketuk. Busana atau kostum yang digunakan oleh pemusik (pangrawit) menggunakan kostum seadanya, walapuan ada kostum seragam berupa koas kelompok namun tidak diwajibkan atau cukup memakai baju yang dikenakan yang berangkat dari rumah masing-masing.

Gambar.7. Seorang Pria Penonton Pria Menampilan Pencungan Ibing Penca

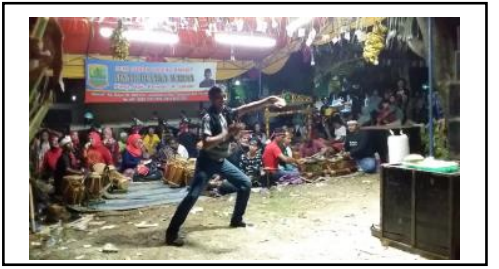

Gambar.8.

Penonton Pria \& Wanita

Berpatisipasi Memberikan Saweran Sambil Berjoget berpasangan dengan ronggeng.

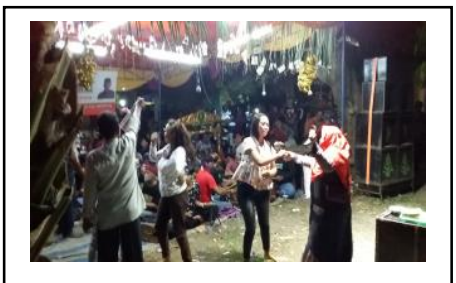

(Sumber Gambar; 7,8 : Rudi Hartono 2020)

Dengan foto diatas memperlihatkan, di awal dengan musik pembukaan para penonton dan undangan didominasi laki-laki dan perempuan. Laki-laki silih berganti memasuki arena pertunjukan lalu menampilkan gerakan pecungan ibing penca yang diiringi oleh musik dengan ketukan kendang yang pas dengan gerakannya, setelah selesai lalu memberikan saweran, apabila tidak puas akan kembali ke depan arena pertunjukan. Beda dengan tamu undangan perempuan hanya ikut berjoget lalu diiringi musik sambel lalu memberikan saweran. Penonton silih berganti dan saling menghormati sambil menunggu giliran yang masuk sebagai partisipasi lalu masuk ke arena dan terlihat terjalin suasana akrab, lalu meminta dukungan para pemain topeng banjet khusus para pemusik untuk mengiringi gerakannya setelah puas lalu menberikan saweran namun ada juga yang memberikan sebelumnya. 


\section{Tarian Pembukaan}

Pertunjukan Topeng Banjet Abah Pendul setelah lagu arang-arang disajikan, ditampilkan tarian yang disebut tari pembukaan. Tarian ini dibawakan oleh seorang penari wanita topeng (ronggeng) yang membawakan tarian ketuk tilu ini mengandung unsur tari dan pencak silat. Ketuk tilu awalnya sebagai tarian upacara meminta hujan, ngalokat cai, panen padi dan upacara hajat bumi. Gerakan penarinya lebih menonjolkan gerak-gerak goyang pinggul. Gerak kepala tidak nampak sama sekali, gerak tangan dan kakipun hampir tidak berarti dibanding dengan gerak pinggul yang aga erotis.

Dalam tarian yang di bawakan oleh seorang penari topeng, seorang penari harus mempunyai dasar pencak silat yang lemah gemulai namun terlihat berisi tenaga, gerak tari khas Topeng Banjet Abah Pendul. Tarian pembukaan ini bertujuan untuk menampilkan gerak-gerak tari gemulai dengan dasar jurus penca untuk menarik perhatian penonton dan siap menangkal lawan yang mau menggangu. Melihat gerak tari yang dibawakan para penonton merasa terpukau untuk menyaksikan pertunjukan Topeng Banjet Abah Pendul secara keseluruhan. Busana khusus yang dipergunakan oleh ronggeng Topeng Banjet Abah Pendul yaitu: Kembang topeng/sayang atau Sarbok yang digunakan di kepala, kain beludru berhias mata yang saling menyilang dibahu kanan dan kiri yang mereka beri nama toka-toka, amben dan amprang (apok) sebagai penutup pinggang dan apok dipasang di belakang. Adapun rias karakter dengan alat rias yang dipakai berupa, pensil alis, lipstik, bedak dasar sesuai kebutuhan pertunjukan.

Gambar.9. Penari Ronggeng

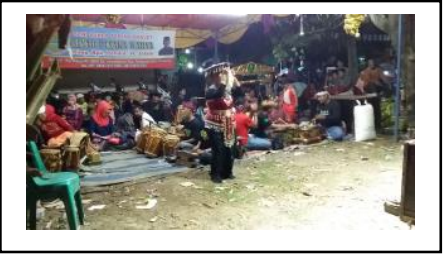

Gambar.10. Penari Siap Manari Ketul Tilu

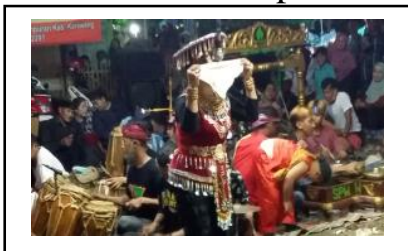


(Sumber Gambar;9,10 : Rudi Hartono 2020)

\section{Lawakan atau Bodoran}

Penyajian lawakan atau bodoran merupakan rangkaian babak yang banyak ditunggu para penonton Topeng Banjet Abah Pendul. Penyajiannya, masuknya seorang pria paruh baya masuk arena pertunjukan. Pemain diiringi dengan musik dengan sambil berjalan memutari peti yang ada di tengah-tengah arena pertunjukan sesekali menampilkan gerakan pencungan ibing pencak. Dengan tanpa sengaja, ia mencoba untuk duduk. Ternyata kursi telah diduduki seorang penari (ronggeng) topeng. Maka ketika itu, terjadi dialog antara penari (ronggeng) topeng dengan pelawak pertama. Pada adegan antara pelawak pertama dengan penari (ronggeng) topeng, tokoh ronggeng topeng berdialog dengan bahasa sunda khas karawang, kadang menggunakan gerak tubuh mirip gerak-gerak erotis dalam beberapa posisi orang tengah melakukan hal tabu. Pemain pelawak kedua dan ketiga muncul mempertanyakan siapa penari (ronggeng), yang tak lain adalah Topeng Abah Pendul. Setalah penari keluar posisi adegan ronggeng topeng diganti oleh pelawak kedua dengan jenaka dan seterusnya lawakan pun berkembang dengan pelawak kedua atau pelawak pertama dan penontonpun tertawa.

Dalam lawakan bahasa yang digunakan adalah bahasa Sunda khas Karawang di tambah pelawak ketiga mengunakan bahasa dialek Jakarte. Penggunaan bahasa verbal yang mereka lakukan dalam menyampaikan lawakan mudah di mengerti, permainan jenaka dalam pertunjukan terjalin komunikatif dan aktraktif dengan penontonnya. Sehingga apa yang mereka lakukan dengan berbagai tingkah lalu dan bahasa dengan kata-kata yang khas serta gaya ekspresi tubuh yang menegaskan karakter masing-masing pelawak membuat penonton pun sungguh terhibur. 
Busana yang dipakai dalam lawakan/bodoran Topeng Banjet Abah Pendul, menggunakan seragam seperti; celana panjang hitam, kemeja lengan pendek dan panjang, rompi, dasi, iket kepala dan kain sarung yang dililitkan pada pinggang. Dengan warna kostum yang kontras mencolok seperti hijau, merah, baju bergaris hitam putih, dan baju polos, ropi di tambah asesories seperti kacamata hitam. Rias yang dipakai rias karakter lucu atau karikatur, disesuaikan dengan peran masingmasing terutama untuk mendukung karakter kelucuan, jenaka, peran karakter para pelawak lihat gambar dibawahkan ini.

Gambar.11. Pelawak Pria

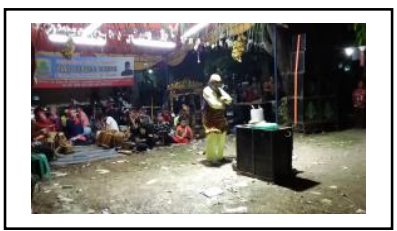

Gambar.12.

Penari (ronggeng) dan Dua Pemain pelawak

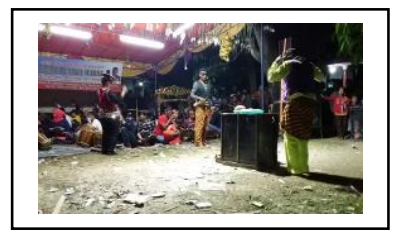

(Sumber Gambar;11,12: Rudi Hartono 2020)

5. Cerita Lakon

Penyajian lakon cerita yang ditampilkan Topeng Banjet Abah Pendul setelah penyajian lawakan. Penyajian lakon cerita utama digelar semalam suntuk sesuai struktur dengan perjanjian di awal yang kadang disesuaikan permintaan punya yang hanjat atau penanggap. Babak lakon atau cerita disajikan rata-rata diatas tiga jam bahkan lebih, ini sangat tergantung pada panjang pendeknya lakon yang dibawakan.

Penyajian lakon cerita dibawakan tergantung permintaan pemesan punya hajat atau diserahkan kepada kelompok Topeng Banjet Abah Pendul. Seperti biasanya sebelum pertunjukan mulai di waktu sore pihak kelompok Topeng Abah Pendul menanyakan ke pihak yang punya acara hajat mau cerita lakon apa di pilih. Apabila yang punya hanjat menyerahkannya kepada pihak kelompok, maka kelompok berembuk dan memutuskan lakon yang disajikan sesuai dengan kondisi dan kesiapan 
pemain. Lakon yang biasa dibawakan oleh kelompok Topeng Banjet Abah Pendul cerita roman keluarga (kisah keluarga), menggambarkan kehidupan sehari-hari masyarakat, jawara, dukung tilu, Dua buronan Nusakambangan, serawak 100 bangkit dari kubur, dll . (wawancara salah satu pemain Wa. Doris 1. Oktober 2020 di pasir malang, Karawang)

Lakon cerita yang biasa dipertunjukan Topeng Banjet Abah Pendul, lakon jenis roman keluarga merupakan lakon yang paling sering disajikan dalam pertunjukan. Lakon cerita tersebut lebih mudah tersampaikan dan dekat dengan kehidupan nyata sehari-hari, sehingga komunikasi dengan para penonton dapat dipahami dengan mudah. Dari beberapa judul lakon roman yang dibawakan Topeng Abah Pendul yang sering mainkan adalah Dua buronan Nusakambangan, Anak Tiri Berdarah Setan, Rusdi Anak Durhaka, Jadud Berontak dalam musyawarah.

Kostum yang dipakai disesuaikan dengan peran yang dibawakan dan rias karakter dilakukan dengan sendiri sesuai karakter peran masing-masing yang akan tampil.

Gambar: 13. Adegan suasana di mulainya lakon cerita berlangsung

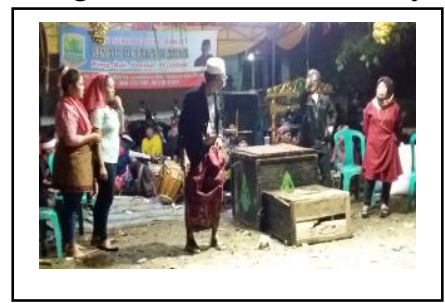

(Sumber Gambar;13: Rudi Hartono 2020)

Berdasarkan observasi, informasi, dan dokumentasi, adapun berbagai jenis perlengkapan dalam proses pembentuk penyajian yang dibutuhkan dalam pertunjukan Topeng Banjet Abah Pendul diuraikan berdasarkan teori struktural Levi-Strauss sebagai berikut.

Tabel.1. Perlengkapan Penyajian 


\begin{tabular}{|c|c|c|c|}
\hline NO & ELEMEN & MODEL & BENTUK \\
\hline 1 & - Tanah Kosong & $\begin{array}{l}\text { - Halaman rumah } \\
\text { - Tanah lapang yang relatif luas }\end{array}$ & $\begin{array}{l}\text { Lahan } \\
\text { Tempat } \\
\text { Pertunjukan }\end{array}$ \\
\hline 2 & $\begin{array}{l}\text { - } 4 \text { Tiang ; ukuran } \pm 3 \mathrm{~m}, \\
\text { berupa besi atau } \\
\text { bambu } \\
\text { - } \text { Terpal } \\
\text { - } \text { Tikar } \\
\text { - } \text { Tali } \\
\text { - } \text { Daun Janur } \\
\text { - } \text { Kue-Kue Kering } \\
\text { (Kerupuk, raginang, } \\
\text { dll) } \\
\text { - } \text { Buah Pisang } \\
\text { - Saund system } \\
\text { - } \text { Lampu }\end{array}$ & $\begin{array}{l}\text { - } 4 \text { Tiang sebagai penyangga tenda } \\
\text { beratapkan terpal lalu dipasang tikar } \\
\text { sebagai alas, tali untuk perekat atap } \\
\text { terpal, daun janur dipasang di bagian } \\
\text { depan tenda menyulur ke bawa, } \\
\text { ujung-ujung daun janur di } \\
\text { ditempelkan dengan cara mengikat } \\
\text { bermacam-macam kue-keu kering, } \\
\text { Buah pisang digantung di sudutTiang } \\
\text { depan kiri dan kanan tenda. Sound } \\
\text { system sebagai pengeras suara dan } \\
\text { lampu sebagai penerangan }\end{array}$ & $\begin{array}{l}\text { Tenda Tempat } \\
\text { Pertunjukan }\end{array}$ \\
\hline 3 & $\begin{array}{l}\text { - Gabah, Ayam bakar } \\
\text { Bakakak dalam Karung } \\
\text { putih } \\
\text { - Kepala Muda } \\
\text { - Rujak-rujakan, } \\
\text { - Kue-kue } \\
\text { - Kolak pisang } \\
\text { - Kopi hitam } \\
\text { - Beras } \\
\text { - Telur ayam } \\
\text { - Daun pandan } \\
\text { - Rokok }\end{array}$ & $\begin{array}{l}\text { - Gabah dimasukan ke dalam Karung } \\
\text { plastik warna putih, lalu Ayam bakar } \\
\text { bakakan di tutup kain } \\
\text { - Kue-kue, kolak pisang, beras, telur } \\
\text { ayam (masing-masing disimpang } \\
\text { dalam wadah kecil-kecil yang } \\
\text { menyerupai gelas), daun pandan } \\
\text { diikat, kopi hitam dalam gelas, rokok, } \\
\text { lalu ditempatkan dalam baki }\end{array}$ & Sesaji \\
\hline 4 & $\begin{array}{l}\text {-Tempat pembakaran } \\
\text {-Api arang } \\
\text {-Kemenyan } \\
\text {-Air putih } \\
\text {-Mangkok } \\
\text {-Kembang bunga }\end{array}$ & $\begin{array}{l}\text { - Asap yang keluar dari api arang } \\
\text { pembakaran di gilir kepada setiap } \\
\text { pemain, lalu asapnya diusapkan } \\
\text { kepada badan para pemain. } \\
\text { - Air putih ditempatkan ke dalam } \\
\text { mangkok dicampur dengan kembang } \\
\text { bunga lalu di percikan pada alat } \\
\text { musik }\end{array}$ & ngukus \\
\hline 5 & $\begin{array}{l}\text { - Rebab } \\
\text { - Kendang } \\
\text { - Goong } \\
\text { - Anggong, } \\
\text { - Kecrek } \\
\text { - Ketuk } \\
\text { - Lagu: }\end{array}$ & $\begin{array}{l}\text { - Dengan perpaduan bunyi,ketukan } \\
\text { dari berbagai alat musik; rebab } \\
\text { kendang,goong,anggong,kecrek,ketuk } \\
\text { menjadi harmonis } \\
\text { - Tatalu mempergunakan bentuk lagu } \\
\text { Arang-arangan Sulanjana }\end{array}$ & Tatalu \\
\hline
\end{tabular}




\begin{tabular}{|c|c|c|c|}
\hline 6 & 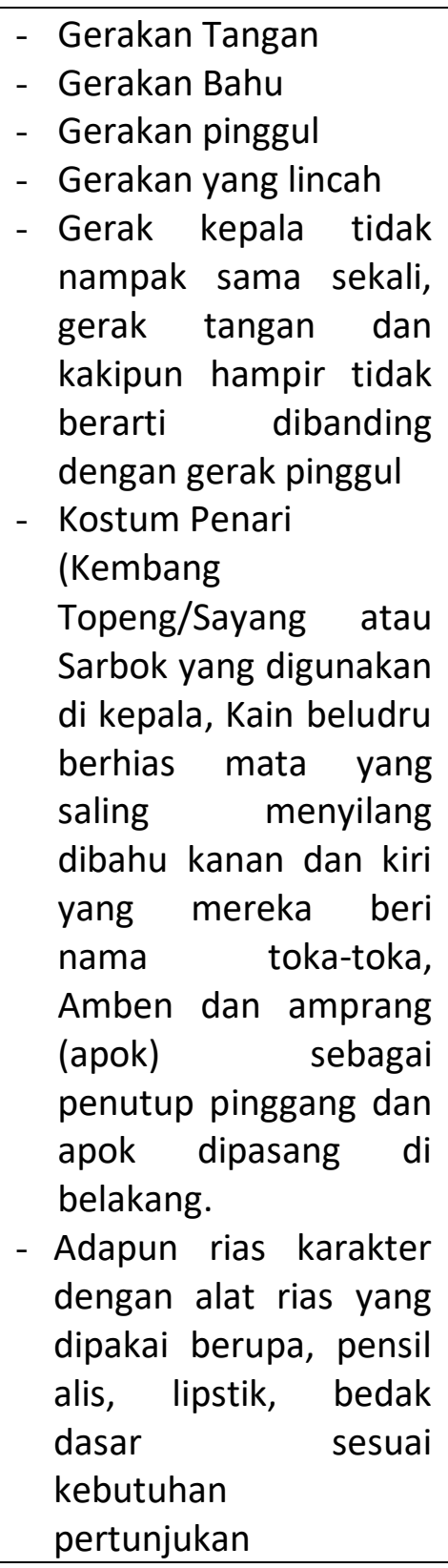 & $\begin{array}{l}\text { - Keluar Topeng dengan lagu Gandes, } \\
\text { Enjot-enjotan, Persi, Balo-balo dan } \\
\text { lagu Oncom Lele } \\
\text { - Gerakan yang lakukan oleh penari } \\
\text { ronggeng, gerakan tangan, bahu, } \\
\text { pinggul serta gerakan yang } \\
\text { ringin pukulan kendang. }\end{array}$ & Tari Ketuk Tilu \\
\hline 7 & $\begin{array}{l}\text { - Pemain } \\
\text { - Ronggeng } \\
\text { - Dialog } \\
\text { - Bahasa Sunda khas } \\
\text { karawang, } \\
\text { - Bahasa Jakarte } \\
\text { - Gerakan Tubuh } \\
\text { - Pencungan Ibing } \\
\text { Pencak } \\
\text { - Kostum Sesuai Karakter } \\
\text { Tokoh } \\
\text { - Make-up apa adanya } \\
\text { - Kumis } \\
\text { - Kaca mata hitam } \\
\text { - Warna Kostum yang }\end{array}$ & 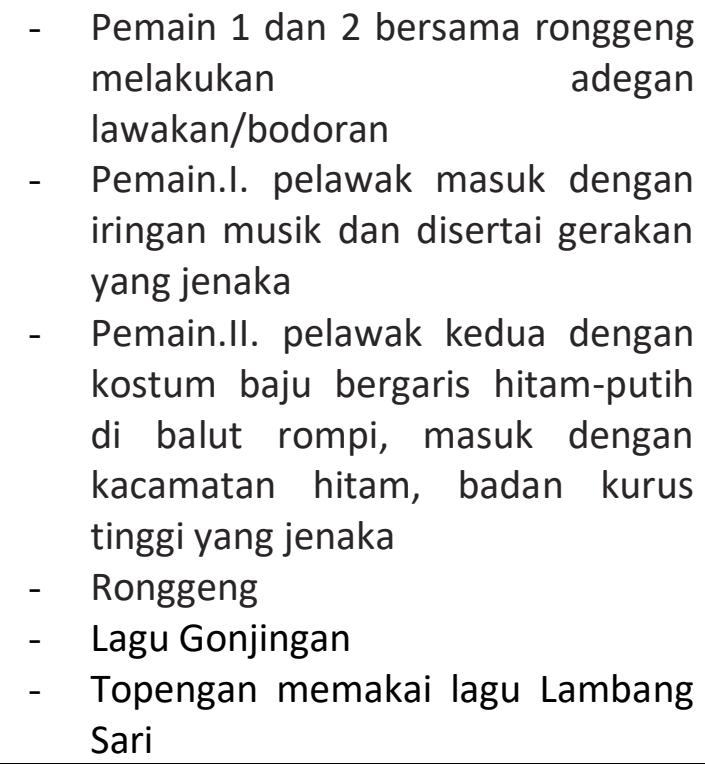 & $\begin{array}{l}\text { Lawakan } \\
\text { Bodoran }\end{array}$ \\
\hline
\end{tabular}




\begin{tabular}{|c|c|c|c|}
\hline & $\begin{array}{l}\text { menonjol kontras, } \\
\text { hijau, Merah, biru, } \\
\text { putih } \\
\text { - Sarung } \\
\text { - Ikat kepala } \\
\text { - Topi } \\
\text { - Ropi } \\
\text { - Dasi } \\
\text { - Adapun rias karakter } \\
\text { dengan alat rias yang } \\
\text { dipakai berupa, pensil } \\
\text { bedak dasar sesuai } \\
\text { kebutuhan pertunjukan }\end{array}$ & $\begin{array}{ll}\text { - } & \text { Rewel mempergunakan lagu } \\
& \text { Rewel; } \\
\text { - } & \text { Lakon mempergunakan lagu-lagu } \\
& \text { apa yang diminta oleh Penari }\end{array}$ & \\
\hline 8 & $\begin{array}{l}\text { - Pemain Pria } \\
\text { - Pemain Perempuan } \\
\text { - Kastum sesuai karakter } \\
\text { pemain masing-masing } \\
\text { - Ikat kepala } \\
\text { - Topi } \\
\text { - Peci haji } \\
\text { - Sarung } \\
\text { - Make-up } \\
\text { keseharian } \\
\text { - Kelakuan-kelakuan yang } \\
\text { melanggar norma } \\
\text { - Kriminalitas } \\
\text { - Kekejaman } \\
\text { - Kelamangan nasib } \\
\text { - Kisah heroic Jawara } \\
\text { - Golok } \\
\text { - Pentungan } \\
\text { - Adapun rias karakter } \\
\text { dengan alat rias yang } \\
\text { dipakai berupa, pensil } \\
\text { alis, listil, bedak dasar } \\
\text { sesuai kebutuhan } \\
\text { pertunjukan }\end{array}$ & $\begin{array}{ll}\text { - } & \text { Jawara } \\
\text { - } & \text { Roman Sejarah } \\
\text { - } & \text { Kisah keluarga menggambarkan } \\
\text { kehidupan sehari-hari masyarakat } \\
\text { tentang kisah rumah tangga } \\
\text { - } \quad \text { Keluar Topeng dengan lagu } \\
\text { Gandes, Enjot-enjotan, Persi, Balo- } \\
\text { balo dan lagu Oncom Lele;Tari- } \\
\text { tarian dengan bentuk-bentuk lagu } \\
\text { Sawilet }\end{array}$ & $\begin{array}{ll}\text { Cerita } & \text { Lakon } \\
\text { (Drama) } & \end{array}$ \\
\hline
\end{tabular}

\section{PEMBAHASAN}

Sebagaimana telah dikemukakan di atas bahwa kajian struktural dalam penelitian ini menggunakan pendekatan struktural yang mengungkap makna dari sebuah objek kajian berdasarkan tinjauan struktur luar dan struktur dalam. Penjabaran dalam pembahasan ini didasarkan pada dua aspek yakni ditinjau dari aspek fenomena kebudayaan dan juga dari seni 
pertunjukan dimana bentuk dan fungsi yang dalam hal ini adalah seni pertunjukan teater rakyat.

Pembahasan mengenai makna estetik pada bentuk dan fungsi pertunjukan Topeng Banjet merupakan pembahasan yang berhubungan dengan kajian struktur dalam. Dalam mengkaji struktur dalam harus memperhatikan apa yang telah disusun pada struktur luar seperti yang telah dijelaskan pada sebelumnya. Adapun pembahasan mengenai makna estetik pada bentuk dan fungsi tersebut dijabarkan sebagai berikut

\section{Kajian Makna Estetik Pada Bentuk Pertunjukan Topeng Banjet Abah Pendul}

Seperti telah diutarakan di atas bahwa analisis struktural menurut Levi- Strauss terdiri dari struktur luar dan stuktur dalam. Struktur luar merupakan sebuah struktur yang tampak secara empiris dan digunakan sebagai pedoman dalam menyusun bentuk pertunjukan Topeng Banjet Abah Pendul tersebut diatas. Pembahasan mengenai makna estetik pertunjukan Topeng Banjet Abah Pendul ini berhubungan dengan struktur dalam digunakan untuk memahami fenomena kebudayaan yang diteliti, namun dalam menganalisis struktur dalam ini harus selalu memperhatikan relasi-relasi yang ada pada struktur luar.

Pembahasan makna estetik pertunjukan Topeng Banjet Abah Pendul terdiri dari pembahasan makna estetik yang dilaksanakan dalam bentuk dan fungsi serta makna estetik yang tersirat dalam simbol-simbol sesaji yang digunakan sebagai syarat dalam melaksanakan pertunjukan Topeng Banjet Abah Pendul. Secara lebih rinci pembahasan mengenai hal tersebut dijabarkan sebagai berikut.

Makna estetik komunikasi simbolis dan keseimbangan hubungan antara manusia, para leluhur (karuhun) dan Tuhan Yang Maha Esa. Nina W.Syam (Saefullah,2007:126-127) dikutip dari Jaeni (2017:67) mendefinisikan komunikasi trasendental sebagai komunikasi yang berlangsung dalam diri dengan sesuatu di luar diri yang disadari keberadaannya. 
Dihadirkanya sesaji bermacam-macam sebagai syarat pelaksanaan dan dilanjutkan ngukus di awal pertunjukan yang dipimpin oleh seorang pimpinan Abah Syahrul Putra Pendul kelompok Topeng Banjet, lalu memanjatkan do'a permohonan dan mantra ucapan syukur atas berkah dan keselamatan yang telah didapat saat ini kepada para leluhurnya dan kepada Tuhan Yang Maha Esa. Lebih lanjut Jaeni (2017;14) menjelaskan, dalam kontek komunikasi, symbol adalah sesuatu yang dipertukarkan, baik dalam komunikasi verbal maupun non-verbal. Komunikasi adalah kegiatan pengoperasian lambang/symbol yang mengandung makna atau arti.

Makna estetik komunikasi budaya (local), Topeng Banjet Abah Pendul sebagai seni temurun memiliki ide atau gagasan melalui symbol-simbol yang hadirkan dalam pertunjukan (tarian, music, lagu, lawakan/bodoran. lakon cerita,) dengan gaya bahasa sunda khas karawang mampu memikat masyarakat pendukungnya di daerah wilayah sekitarnya dengan system makna nilai budaya yang terjalin dengan baik dan sudah berlangsung lama hingga saat ini menjadi fenomena budaya.

Makna estetik komunikasi bagi penanggap (pewaris pasif), di dalam keluarga tersebut sudah pernah sebelumnya melaksanakan pertunjukan Topeng Banjet secara turun-temurun sebagai pelengkap upacara hajatan. Upacara hajatan dilaksanakan pada waktu peralihan musin ditandai setelah selesai panen padi, dan memilih hari yang tepat lalu mengundang Topeng Banjet Abah Pendul dalam upacara syukuran hasil panen, kawinan, khitanan, dan lain-lain,

Makna estetik komuniasi bagi tamu undangan (pria dan wanita), penanggap mengundang keluarga terdekat sanak saudara dan handai tolan, kerabat jauh, teman dan sahabat turut bersuka cita dalam kegiatan hajatan tersebut. Mereka yang datang memiliki kemampuan ekonomi lebih. Dalam perhelatan upacara hajatan tersebut tamu undangan menyaksikan pertunjukan Topeng Banjet Abah Pendul. Ada beberapa tamu undangan yang 
disebut namanya dan puja-puji oleh sinden disertai lagu dan mendapat sorotan mata tertujuk kepadanya dan sorakan, tepuk tangan, dari tamu yang lain dan penonton, dengan muka berseri-seri tamu tersebut beranjak dari tempat duduknya dan maju berjalan masuk arena pertunjukan tamu lalu pria spontan menampilkan gerakan pencungan ibing pencak yang diringin musik dengan tabuhan ketukan kendang yang tepat. Setelah selesai tamu pria tersebut memberikan saweran yang lumayan banyak. Dari beberapa tamu yang tampil saling bersaing ada memberikan saweran, ada yang mulai dari ratusan ribu sampai jutaan rupiah kepada pemain musik dan sinden. Sedangkan tamu wanita yang yang disebut namanya tidak mau kalah saingan, langsung masuk berjoget bersama ronggeng perempuan diiringin musik dan lagu sambil mengeluarkan uang kertas lembar per lebar dari tangan dan dicabut oleh ronggeng sampai habis dan selesai satu lagu bahkan bisa lebih. Disini tamu undangan setelah tampil mendapat hiburan dan kebanggan secara individu dapat hadir ditengah pertunjukan dan saksikan oleh banyak orang membuktikan status sosialnya.

Makna estetik komunikasi penonton yang berasal dari masyarakat atau bisa disebut warga kampung sekitar tempat pertunjukan. Mereka datang menonton atas dasar kekeluargaan, pertemanan dan ikatan emosional kebersamaan warga serta kebetulan memiliki waktu luang. Penonton datang untuk bersuka cita menyaksikan pertunjukan Topeng Banjet Abah Pendul mulai dari awal sampai akhir pertunjukan dapat menyaksikan, langsung tarian, musik, lagu, lawakan, cerita lakon dengan jelas hingga terlibat dalam arena pertunjukan suasana akrab dan menyatu, spontanitas di karena jarak pertunjukan tidak ada batas. Penonton yang datang tidak mendapat aturan ketat misalnya duduk dimana saja, sambil makan dan minum, sambil ngobrol satu sama lain dan merokok. Di tengah-tengah penyajian pertunjukan ini penonton terlibat seperti menampilkan pencungan ibing penca, menjadi pemain dadakan, tercipta dialog pemain dengan penonton atau sebaliknya, tertawa bersama, berjoget bersama, dan menyanyi bersama. Di sela-sela pertunjukan kadang penonton 
melemparkan saweran dari luar ke dalam arena pertunjukan, dan kadang pemain atau ronggeng memungut saweran dari penonton dengan cara berkeliling menyapa, adapun saweran berupa uang, minuman kemasan, kue, rokok, dan lain-lain. sanak saudara dan handai tolan Di sini pertunjukan Topeng Banjet Abah Pendul sebagai hiburan di waktu luang. Kajian Makna Estetik Pada Fungsi Pertunjukan Topeng Banjet Abah Pendul dalam Perspektif Seni Pertunjukan

Seni pertunjukan di Indonesia berangkat dari suatu keadaan dimana ia tumbuh dalam lingkungan-lingkungan budaya local atau ethnic tertentu yang berbeda satu sama lain. Sebunungan dengan fungsi pada pertunjukan teater seperti halnya dengan peranan dan fungsi teater menurut soetarno, menyebutkan terdapat sepuluh fungsi sosial yang berkaitan dengan pertunjukan wayang (teater) yaitu (1) fungsi penghayatan estetis, (2) fungsi hiburan, (3) fungsi presentasi estetis, (4) fungsi sebagai ungkapan jati diri, (5) fungsi berkaitan dengan norma sosial, (6) fungsi pengesahan lembaga sosial dan ritus keagamaan, (7) fungsi sebagai sarana pendidikan, (8) fungsi pengintegrasian masyarakat, (9) fungsi kesinambungan budaya, dan (10) fungsi sebagai lembaga penuh makna dan mengandung kekuatan (dalam Sarwanto, 2008:204) dikutip dari Saaduddin, (2016). Adapun pertunjukan Topeng Banjet Abah Pendul, fungsi pertunjukan bila merujuk pada fungsi diatas teridentifikasi pada fungsi pertunjukan sebagai berikut: Pertama, sebagai sarana ritual upacara, pengucapan syukur atas hasil panen telah peroleh yang diberikan dari Tuhan Yang Mah Esa, begitu juga pada acara hajatan kawinan, khitanan, dan lain-lain. Rasa syukur ini oleh masyarakat pendukung (penanggap) dilakukan turut membentuk penanaman nilai-nilai moral dan bersuka cita bersama ditengah warga kampung. Dengan proses memahami dan penanaman nilai-nilai budaya local selama proses pertunjukan, maka para penonton telah di berikan kesadaran budaya sementara penanggap telah memiliki kesadaran budaya secara turun termuru. Kedua, sebagai sarana hiburan ditujukan kepada orang-orang yang datang hadir ke undangan hajatan dan penonton 
yang berpartisipasi dalam pertunjukan. Ini disajikan untuk menghibur tamu undangan yang berkunjung dan disuguhkan pertunjukan kesenian di siang hari dan malam hari. Topeng Banjet Abah Pendul sebagai wujud karya cipta seni salah satunya memiliki fungsi hiburan dengan hadirnya artsitik, musik, lagu, tari dan pemain di dalam pertunjukan ada lawakan atau bodoran menyebabkan tamu, penonton dan pengamat, dengan pertunjukan tersebut dapat memberikan kesenangan dan kepuasan pada umumnya. Eskpresi kesedihan, kegembiraan, kelucuan, ketangkasan, terpesona, menghasilkan efek hiburan kepada penonton. Ketiga, sebagai sarana komunikasi karya seni menyampaikan ide atau gagasan yang merupakan pesan moral sesuai isi tema lakon cerita. Memiliki keindahan kinestetik dengan adanya gerakan yang terpola dan teratur dengan acting dan tarian. Dialog antar pemaian dan dialog kadang-kadang melibatkan penonton masuk arena pertunjukan sebagai pemain dadakan dan penonton berpartisipasi bergoyang diiringi lagu-lagu dan bersama ronggeng serta penonton dan tamu undangan pria masuk ke arena pertunjukan memperlihatkan Pencungan Ibing Penca yang dikuasai serta diiringan music ketukan kendang yang sesuai gerakan dan penontonnya merasa puas dan lalu memberikan saweran. Keempat, sebagai sarana presentasi artistik dengan hadirnya unsur-unsur artistic dimana segala unsur kreasi seni pendukung pertunjukan yang menjadikan panggung lebih hidup yang meliputi, Tata panggung atau tenda dimana tempat para pendukung berada dihiasi dengan janur kuning, daun beringin, tampak dari depan di disela-sela janur digantung berbagai macan kue-keu kering seperti kerupuk, ranginang, serta buah pisang, dan hanya beralaskan tikar diatas tanah yang ditempati. Tata rias penari ronggeng dan tata rias karakter para pemain, tata busana terlihat dari penari ronggeng dan para pemain dengan menggunakan kostum yang sesuai dengan peran masing-masing yang akan dimainkan, pencahayaan dalam pertunjukan dengan menggunakan lampu sebagai penerangan seperti lampu neon TL berukuran $30 \mathrm{Cm}$ dan lampu sorot halogen atau flat 300500 Watt, dan tata suara dengan menggunakan sound system dimana speaker alat untuk 
membesarkan suara yg dihasilkan oleh mikrofon, dan mikrofon untuk alat yg mengeraskan suara alat music, sinden dan pemain sehingga suaranya dapat terdengar denga jelas dari jarak radius jauh dari arena pertunjukan. Kelima, sebagai sarana fungsi berkaitan dengan norma social dalam pertunjukan lakon cerita drama yang pada umumnya berkisah tentang JawaraJawara yang heroic, kehidupan keluarga, kriminalitas, kekejaman, kemalangan nasib, serta kelakuan-kelakuan yang melanggar norma social yang berlaku ditengah masyarakat yang tidak dapat diterima oleh sebagaian masyarakat pada umumnya dengan menggambarkan kehidupan masyarakat kelas bawah di akhir cerita adanya hadir tokoh petugas atau aparat pemerintahan untuk menangkap pelaku antagonis dan diberikan sanksi-saksi baik secara tertulis maupun tidak. Keenam, sebagai sarana pendidikan teater rakyat sebagai seni kolektif dalam pertunjukan Topeng Banjet Abah Pendul dukungan pemain \pm 29 Orang (sinden, penari, pemusik,dan pemain actor dan aktris), artinya teater tidak bisa dilakukan oleh satu orang, tetapi melainkan harus dilakukan dengan banyak orang. Lewat teater, orang akan diajak untuk berorganisasi dan bekerja sama. Dalam pertunjukan, teater akan memberikan pesan-pesan kepada penonton. Melalui lakon cerita yang dimainka, penonton tidak terasa dididik untuk mengerti kebaikan dan kejahatan. Ketujuh, sebagai sarana pengintegrasian masyarakat. Pertunjukan Topeng Banjet Abah pendul, merupakan kesempatan bagi pelaku seni Topeng Banjet Abah Pendul dari Karawang berkeliling di wilayah pentas untuk bertemu, dan bertukar informasi. Pelaku dan penikmat teater rakyat di Jawa Barat datang menonton pertunjukan sebagai masyarakat penyanga pewaris pasif, karena tema yang diangkat dekat dengan realitas sosial masyarakat sehari-hari. Kedelapan, fungsi sebagai sarana kesinambungan budaya pra modern dan modern dilihat dari sistem ritual kepercayaannya, adanya upacara syukuran hasil bumi (setelah panen padi) yang dilakukan oleh penanggap pada era modern saat ini dengan cara memberi sesajen atau sesajian pada pada awal pertunjukan yang dianggap symbol itu menunjukkan bahwa masyarakat zaman 
sekarang masih menganut sistem kepercayaan pada zaman dulu. Kesembilan, fungsi sebagai lembaga penuh makna dan mengandung kekuatan. Dalam setiap tahapan penyajian struktur pertunjukan Topeng Banjet Abah Pendul, simbol budaya sebagai bahasa komunikasi dipahami dilaksanakan dalam pertunjukan mulai dari penyediaan perlengkapan sesaji dan ngukus di yang lakukan di awal pertunjukan disertai bacaan doa dan mantra oleh pimpinan kelompok bermakna sebagai ucapan syukur dan permohonan kepada Tuhan Yang Maha Esa dan para leluhur atas keberkahan hasil panen di peroleh oleh penanggap dan juga warga kampung serta mendapat kelancaran pertunjukan sampai selesai. Tetalu atau musik iringan dan lagu penuh dinamis dan harmoni sebagai pembukaan seolah-olah menyapa penonton dan mendapat respon berupa, saweran, sorakan dan tepukan tangan sambil bersiul dan lain-lain. Tarian ketuk tilu (tari klasik) dengan penari ronggeng lengkap dengan kostum, gerakan tarian ini lebih banyak memadukan gerakan pinggul, lengan, bahu, kepala, dan tangan, menjadi suatu rangkaian gerak yang dinamis. Gerakannya terlihat dinamis, energik, seksi, dan anggun. Sering kali para penari juga berpindah-pindah membentuk formasi yang menarik. Gerakan gitek, geol, dan goyang, yang menjadi khas ketuk tilu dimaknai tarian persembahan juga sebagai upaya memikat para tamu undangan dan penonton yang ada di arena pertunjukkan, sedangkan gerakan pencungan ibing pencak sebagai penggambaran cara untuk melawan orang yang akan berniat mengganggu. Lawakan atau bodoran dengan penampilan jenaka para pemain bobodoran dalam kamus Lembaga Basa jeung Sastra Sunda (LBSS) berarti purah nyieun pikaseurieun batur (kelakuan yang membuat orang lain tertawa). Dalam budaya masyarakat Sunda bodor seperti sebuah kebiasaan dalam obrolan, baik itu dalam pertemuan sehari-hari atau resmi sekalipun. Bodor sendiri sepertinya sudah watak dalam masyarakat Sunda, sehingga bodor merupakan salah satu ciri khas dalam masyarakat Sunda yang mempunyai sifat humoris. Dapat dimaknai oleh tamu undangan dan penonton sebagai hiburan pelepas penak dan terbebas dari rutinitas keseharian. Lakon cerita (drama) dalam 
pertunjukan Topeng Banjet Abah Pendul yang pada umumnya berkisah dengan bertema Jawara-Jawara yang heroic, kehidupan keluarga, kriminalitas, kekejaman, kemalangan nasib, serta kelakuan-kelakuan yang melanggar norma yang tidak dapat diterima oleh sebagaian masyarakat pada umumnya dengan menggambarkan kehidupan masyarakat kelas bawah. Dari lakon cerita ini dimaknai sebagai suatu peristiwa atau kejadian yang disampikan kembali melalui tindak-tanduk pemain tersebut melalui pesan kritik social dapat lebih dalam lagi dimaknai pesan moral kepada tamu undangan dan penonton.

\section{KESIMPULAN}

Dari hasil penelitian yang sudah dilakukan pada Pertunjukan Topeng Banjet Abah Pendul, yakni menganalisis penyajian bentuk dan fungsinya, maka hal ini dilakukan sebagai satu kesatuan guna mencapai tujuan menemukan kolerasi-kolerasi makna estetik pada pertunjukan. Sedangkan proses pe-makna-an estetik yang terjalin pada pertunjukan Topeng Banjet Abah diantaranya;

1. Dihadirkanya perlengkapan sesajian dan kegiatan ngukus dalam pertunjukan Topeng Banjet Abah Pendul masih terjalin komunikasi trensendental dalam menjaga dan keseimbangan hubungan antara manusia, para leluhur (karuhun) dan Tuhan Yang Maha Esa, wujud makna estetik keberkahan dan keselamatan sebagai upacara ucapan syukur.

2. Kebudayaan local sebagai hasil ide atau gagasan masyarakatnya telah menghasilkan bentuk dan fungsi Topeng Banjet Abah Pendul, dengan melalui symbol-simbol yang digunakan terjalin komunikasi budaya dalam pengalaman estetis penanggap telah berlangsung secara turun-temurun sebagai makna estetik perekat nilai-nilai dalam masyarakat seperti, upacara syukuran, aktualisasi, hubungan kekerabaran, dan hiburan. 
3. Dalam Pertunjukan Topeng Banjet Abah Pendul, tamu undangan dan penonton dengan berbagai latar belakang social turut menpengaruhi dalam memperoleh makna estetik masing-masing sesuai kepentingannya.

4. Makna estetik sangat subyektif secara personal dimana pengalaman estetis diperoleh melalui relasi-relasi nilai bentuk dan fungsi melalui symbol baik secara verbal dan non-verbal mendapat respon secara indrerawi.

\section{Saran}

Berdasarkan penelitian ini maka saran yang bisa diberikan yaitu ;

1. Perlunya dari berbagai pihak untuk pelestarian budaya pertunjukan Topeng Banjet Abah Pendul sebagai aset budaya bangsa yang memiliki nilai-nilai kearifan dan makna estetik budaya local menjadi salah satu bentuk dan fungsi kesenian dalam persaingan kompetitif dalam era digitalisasi.

2. Mendorong pemerintah setempat membuat kalender event budaya khusus yang setiap peralihan musim panen menjadikan pertunjukan Topeng Banjet Abah Pendul peristiwa budaya local yang ada di Jawa Barat.

3. Pengembangan dan Pemberdayaan budaya local pada Topeng Banjet Abah Pendul melalui pariwisata pertunjukan seni agar dapat mendorong daya ungkit ekonomi di tengah-tengah masyarakatnya.

\section{SUMBER BACA /PUSTAKA :}

Ahimsa-Putra, Henddy Shri. (2009). Strukturalisme Levi-Strauss, Mitos dan Karya Sastra, Yogyakarta, Kepel

Berger, Arthur Asa. (2010). Pengantar Semiotika: Tanda-Tanda Dalam Kebudayaan Kontemporer, Yogyakarta: Tiara Wacana.

Bleicher, Josef. (Tanpa Tahun). Hermeneutika Kontemporer: Hermeneutika sebagai Metode, Filsafat, dan Kritik. Terjemahan oleh Ahmad Norma Permata, Yogyakarta: Fajar Pustaka Baru.

Fiske, John, 2012. Introduction to Cummunicaton Studies. Diterjemahkan oleh Dwiningtyas, Hapsari, Pengantar Ilmu Komunikasi. Jakarta: Rajawali Pers

Hawkes, T. (1978). Structuralism and Semiotics. London: Methuen \& Co. Ltd

Heriyawati, Y. (2016). Seni Pertunjukan dan Ritual, Yogyakarta, Ombak 
Hermawan,D \& Damayanti,IS. (2017). Antropologi Seni, Pendekatan, Teori, Metode dan Aplikasinya, Bandung : Pasca Sarjana ISBI Bandung,

Jeani. (2017). Komunikasi Seni. Bandung: Program Sarjana STSI Bandung

Nugrahani,F. (2014). Metode Penelitian Kualitatif dalam Penelitian Pendidikan Bahasa, Surakarta

Satoto, S. (2012). Analisis Drama \& Teater Bagian 1, Yogyakarta :Ombak

Santoso, E. (2020). Kemuliaan Teater Catatn Tentang Teater, Aktor, dan Pendidikan, Yogyakarta: Diandra Kreasi

Susanto, E. H. (2012). Iklan politik dan kegagalan partai politik" dalam media dan komunikasi politik (ed. Heri Budianto). Jakarta: Litera

Sumardjo, Jacob (2010). Estetika Padadoks, Edisi Revisi. Bandung: Sunan Ambu Press

Suryajaya, M. (2016). Sejarah Estetika: Era Klasik sampai Kontemporer, Jakarta: Gang Kabel

\section{Jurnal}

Jaeni. (2012). Komunkasi Estetik dalam Seni Pertunjukan Teater Rakyat Sandiwara Cirebon,Jurnal Seni \& Budaya Panggung, Vol.22 April-Juni 2012

Mudjiyanto.B \& E Nur,E. (2013). Semiotika Dalam Metode Penelitian Komunikasi Semiotics In Research Method of Communication, Jurnal Penelitian Komunikasi, Informatika dan Media Massa - PEKOMMAS, Volume 16 No. 1 April 2013

Prasanti, D. (2018). Penggunaan Media Komunikasi Bagi Remaja Perempuan Dalam Pencarian Informasi Kesehatan: Studi Kualitatif tentang Penggunaan Media Komunikasi bagi Remaja Perempuan dalam Pencarian Informasi Kesehatan, Jurnal Lontar vol. 6 no 1 januari-juni 2018, 13-21

Rosala, D. dkk. (2018). Pencugan Ibing Penca Topeng Pendul Kabupaten Karawang, Jurnal Panggung Vol. 28 No. 1, Maret 2018

Saaduddin. (2016). Analisis Bentuk, Fungsi dan Makna Pertunjukan Teater Tanah Ibu Sutradara Syuhendri. Jurnal Expresi Seni, Volume 18, Nomor 1,Juni 2016

Setiawan R.B, dkk. (2018). Kajian Struktural Wanda Wayang Durga Dalam Perspekstif Cerita Pewayangan Sudamala Dan Budaya Jawa, Jurusan Pendidikan Bahasa dan Sastra Jawa Pascasarjana, Universitas Sebelas Maret Surakarta, Widyaparwa, Volume 46, Nomor 1, Juni 2018

Verawati, N. (2016). Pergeseran Pemanfaatan Instagram Sebagai Media Bisnis Online (Studi Kasus pada Akun @ Schonehazzle), KOM DAN REALITAS SOSIAL Jurnal Ilmu Komunikasi, Volume 12, Nomor 12, April 2016

\section{Website}

https://www.dosenpendidikan.co.id/semantik-adalah/

https://www.ilmusaudara.com/2016/12/pengertian-seni-fungsi-dan-pembagian.html

https://ilmuseni.com/dasar-seni/pengertian-estetika-menurut-para-ahli

https://saidnazulfiqar.wordpress.com/2010/12/29/makna-dan-teori-tentang-makna-tugas/

https://serupa.id/pengantar-estetika-filsafat-keindahan-rasa-dan-selera/ 